\title{
Monitoring Selected Species of Mammals in Grand Teton National Park From 1999 ThroUgh 2003
}

\author{
BRIAN MILLER $\uparrow$ DENVER ZOO \\ DENVER CO \\ HANK HARLOW $\downarrow$ DEPT. OF ZOOLOGY \& PHYSIOLOGY \\ UNIVERSITY OF WYOMING $\uparrow$ LARAMIE
}

\section{INTRODUCTION}

Understanding abundance, distribution, habitat choice, and ecological interactions of mammalian species can promote management decisions that benefit overall ecosystem health. Monitoring programs that build an ecological model of the landscape, and assess the trends in relation to biotic and abiotic changes, are essential to adaptive management, yet are seldom a standard part of management activities (Sinclair 1991; Noss and Cooperrider 1994; Lancia et al. 1996; Noss et al. 1996). Monitoring implies a repeated assessment of status. In other words, the single year is placed into a larger context (Thompson et al. 1998). Indeed, a conservation plan requires a long-term obligation to standardized ecological monitoring so that actions can be adjusted according to new information (Noss et al. 1996).

Over the long term, this standardized monitoring plan will provide information on small and medium-sized mammals that will (1) assess species use of habitat, (2) monitor changes in species composition as a result of environmental change, and (3) analyze the impact of wolf (Canis lupus) colonization on the mammal (and plant) community. If data become tight enough, we could formulate a predictive model for mammal and habitat relationships.
The abundance and diversity of mammals can be greatly affected by a number of factors. These include plant productivity (Hunter and Price 1994; Krebs et al. 1995; Polis and Strong 1996), climate (Pinter 1996; Hoogland 1995; Post et al. 1999), natural disturbance (Pickett and White 1985), disease (Dobson and May 1986), environmental change (Lancia et al. 1996; Thompson et al. 1998), and changes in numbers of large predators (McLaren and Peterson 1994; Terborgh et al. 1999; 2001; Crooks and Soulé 1999; Crête 1999; Oksanen and Oksanen 2000; Miller et al. 2001).

\section{$\downarrow \quad$ METHODS}

The Pacific Creek study area is a $100 \mathrm{~km}^{2}$ rectangle. It is roughly bounded by Jackson Lake on the west (UTM boundary is E533000) and by Signal Mountain on the south (UTM boundary is N4855000). To the east, the study area is bounded by the west edge of the Buffalo Ranger District of the U.S. Forest Service (Grand Teton National Park boundary east of Pacific Creek Road-UTM is E542700). The northern border of the study area is the boundary between the Grand Teton National Park and the Buffalo Ranger District that lies north of Two Ocean Lake (UTM is N4864000).

The south study area is roughly the same size, and it was added in 2002. This area is bounded 
by Highway $26 / 287$ on the north (about $4854000 \mathrm{~N}$ ), the Snake River on the west, and the south (4847000 $\mathrm{N})$ and east boundaries (547000 E) of the Grand Teton National Park. The south area surrounds the Elk Ranch Reservoir.

The five vegetation types we sampled followed the maps and habitat designations created by Debinski et al. (1996). The habitats we sampled included mature stands of lodgepole pine (Pinus contorta) (P1), dry sage (Artemisia tridentata) (M6), mixed grasses and forbs (M3), sedge/grass/willow damp meadow (M2), and sedge-grass swamp (M1) (see Debinski et al. 1996).

In the Pacific Creek area, we sampled one plot at each of these habitat types in 1999, but in 2000 and 2001 we sampled the original plot from 1999 plus one replicate in each habitat type. The 5 initial plots analyzed in 1999 have been also analyzed every year from 1999 through 2003. These same 5 locations in the Pacific Creek area will be trapped each year into the future. In 2002 and 2003, there were no second replicates in the Pacific Creek area because we expanded the trapping effort to include a second study area around the Elk Ranch Reservoir.

In the Elk Ranch Reservoir area, we sampled plots of one hectare each in M6 habitat, M3 habitat, M1 habitat and P1 habitat. There was not an M2 plot of sufficient size for a one hectare trapping grid. Each of these plots will be trapped each year into the future.

We followed the standard capture-recapture techniques for small mammals (e.g. mice and voles, see Clark and Stromberg 1987) using folding Sherman traps that are $22.5 \mathrm{~cm}$ long and 7.5 by 7.5 $\mathrm{cm}$ wide. Bait was rolled oats that were coated with molasses. Rodents were marked with ear tags purchased from National Band and Tag (size 1 Monel alloy tags). We tested this method in the Grand Teton National Park during 1999 and all tags were retained on captive mice and voles during a threeweek trial. Trapping sessions typically last 7 to 10 days. From 2000 to 2003, eight individuals have been recaptured a year after marking and they retained the ear tag from the previous year. Three individuals of Tamias have been recaptured and retained their tag for two consecutive years (marked in 2001 and recaptured in 2002 and 2003).

In 1999 - 2001, we trapped a site continuously until recaptures roughly equal new captures. After 2002, we stopped the trapping after we reached 1,000 trap-nights. For this reason, the sampled area was considered a closed population (Caughley 1977; Lancia et al. 1996; Thompson et al. 1998). Low sample size on some plots precluded the use of program CAPTURE (White et al. 1982), so we estimated abundance using the Peterson estimate with the Chapman adjustment (Peterson 1896; Chapman 1951; Caughley 1977; Lancia et al. 1996; Thompson et al. 1998).

In addition, we used regression formulas to convert total unique capture numbers over the total number of trap nights at a plot into unique captures per 1,000 trap-nights (Caughley 1977). The dependent variable was number of unique captures. The independent variable was number of trap-nights (effort). Number of trap-nights was adjusted for sprung traps via the technique of Beauvais and Buskirk (1999).

We compared the number of unique captures per 1,000 trap-nights to estimates of abundance in each habitat type using simple linear correlation and the Spearman correlation index (Zar 1984). We used Chi-squared tests to see if species numbers varied across years on the same plot (Zar 1984).

The grid size for each of the five habitat types that are trapped every year (1P1, 1M6, 1M3, $1 \mathrm{M} 2,1 \mathrm{M} 1)$ is 1 hectare. Traps within these grids were spaced every 10 meters (121 traps per 1 ha grid). The population size associated with a grid is a function of two known factors (grid area and perimeter) and two unknown factors (boundary stripwidth and true animal density) (Otis et al. 1978; Lancia et al. 1996). So, in 2001, we analyzed unique captures for each of these five grids as a series of nested grids that are $0.2 \mathrm{ha}, 0.4 \mathrm{ha}, 0.67 \mathrm{ha}$, and $1 \mathrm{ha}$ to provide a regression slope comparing number of captures to size of grid. This assesses the impact of the boundary strip and estimates the feasibility of trapping grids smaller than 1 ha (Otis et al. 1978; Lancia et al. 1996). The adjusted $r^{2}$ for the five habitat types ranged from 0.85 to 0.96 (Table 1). Thus, the relationship between captures in relation to grid size is very tight (the scatter of points is a close fit to the theoretical slope of the equation).

Table 1. Regression formulas when comparing .2 ha, .4 ha, $.67 \mathrm{ha}$, and 1 ha to new captures for each of the 5 habitat types in year 2001. Abbreviations follow the pattern established in the text. All $p$ values less than 0.01 .

\begin{tabular}{|lll|}
\hline \hline Habitat & Adj. $\mathrm{r}^{2}$ & Formula \\
\hline 1M6 & 0.85 & $\mathrm{Y}=0.0895062 \mathrm{X}+5.32407$ \\
1P1 & 0.90 & $\mathrm{Y}=0.0470679 \mathrm{X}+4.50231$ \\
1M3 & 0.96 & $\mathrm{Y}=0.0509259 \mathrm{X}+2.48611$ \\
1M2 & 0.94 & $\mathrm{Y}=0.3086420 \mathrm{X}-7.79630$ \\
1M1 & 0.93 & $\mathrm{Y}=0.3202160 \mathrm{X}+7.15509$ \\
\hline
\end{tabular}


Species not easily seen or trapped were estimated via an index thought to be correlated with abundance (Caughley 1977; Lancia et al. 1996). For example, we counted fresh mounds of northern pocket gopher (Thomomys talpoides) and badgers (Taxidae taxus) within the 1 ha grid. We determined fresh digs by presence of soil on the mound that had not yet hardened in the sun. In addition, we counted all animal sign by walking transects that were $100 \mathrm{~m}$ long and 5 meters wide until the entire one hectare grid was surveyed. This information can be used as a measure of presence/absence.

We are estimating numbers of some small and medium-sized carnivores by collecting and genotyping feces, following the two techniques used by Kohn et al. (1999) to estimate coyote (Canis latrans) population numbers. Genetic analysis involves molecular typing with microsatellite markers (see Kohn et al. 1999). Genetic work is being done at Aurora College in Denver, where Dr. Anna Goebel has a working laboratory and is presently extracting microsatellite markers from scat. Estimating population numbers is a very nonintrusive method of collecting reliable data (Kohn et al. 1999).

To collect the scat, we divided the study areas into 11 different cells that are $9 \mathrm{~km}^{2}$ each. The smallest published coyote home range in Wyoming is $10 \mathrm{~km}^{2}$ (Clark and Stromberg 1987). Each cell had at least two trails running through it, and there is nowhere inside a map of our northern study area that we could place a cut-out square equaling $3.17 \mathrm{~km} \mathrm{X}$ $3.17 \mathrm{~km}$ or a $5 \mathrm{~km} \mathrm{X} 2 \mathrm{~km}$ rectangular cut-out without crossing at least two trails. In the area around Elk Ranch Reservoir, we avoided the area around the wolf den. That area could contain the cutout square without crossing a trail.

During 2001-2003, we walked a distance of $95.5 \mathrm{~km}$ on trails in late June and collected all fresh scat that we saw. Four weeks later, we walked the same trails to again collect all fresh scat. We recorded the distances of habitat types M6, P1, M3, and M2 along each transect, and we recorded the habitat type where each fresh scat was located. Because M1 habitats are swampy, there are very few trails through that habitat type. During 2002 and 2003 , we also walked $47.5 \mathrm{~km}$ of trails around the Elk Ranch Reservoir to collect fresh scat. Again, we recorded the distance each trail passed through the habitat types and the habitat type where we located each fresh scat. Fresh scats were determined subjectively but by the same people each year. A scat was fresh if its color was black and the mucosal lining shined. We used Chi-square tests for analysis of scat numbers and locations (Zar 1984).

Through DNA analysis, populations for coyotes may be analyzed with the Peterson technique (Peterson 1896; Chapman 1951). Smaller carnivores have smaller home ranges, so we may not use the Peterson analyses to estimate their population numbers, but because we walk the same trails each year such data provide an index of trends in populations.

We collected scat from trails to ensure a higher capture probability, thereby strengthening the estimates (Karanth and Nichols 2000). While random sampling is best for estimating rodents that are evenly distributed in a homogeneous vegetation type, the situation is different for carnivores covering heterogenous habitats and not using those habitats equally. Sampling from areas not likely frequented by the animal will lower the number of "captures" and therefore lower precision. In the comparisons we seek, precision is of utmost importance (Karanth and Nichols 2000).

Over time, the impact of wolf colonization on small and medium-sized mammals may be analyzed with a time-series analysis, linear regression, a non-parametric Mann-Kendall test of trends (Mann 1945; Kendall and Gibbons 1990), and appropriate univariate and multivariate techniques (Zar 1984). Results are accepted as statistically significant when $p$ values are 0.05 or less unless otherwise indicated. Caughley (1977), Zar (1984), and Thompson et al. (1998) were the reference texts for statistics, and we used the program Systat 7.0. All regression formulas present the adjusted $r^{2}$, which is more conservative than $r^{2}$.

\section{RESULTS AND DISCUSSION}

Table 2 shows a comparison of unique captures per 1,000 trap nights within the same 1 ha site among the years 1999-2003. The linear regression nearly always describes captures as a function of trap nights within the range of observed values for trap nights. If there is good reason to believe that the described function holds for values of $X$ outside the range of those observed, then extrapolation can be done cautiously (Zar 1984). In four cases ( 1 in 2000 and 3 in 2001, we extended the relationship of captures to trap nights by 15 to $30 \%$, but the adjusted $r^{2}$ was very high $(0.83,0.92,0.95$, and 0.97). 
Table 3 uses the formulas in Table 2 to compare number of unique captures per 1000 trapnights within the same plots (e.g. 1M6 to 2M6) among years. Table 4 uses the formulas of Table 2 to compare unique captures per 1,000 trap-nights in two replicates of the same habitat type during 2002 and 2003. One of those replicates for each habitat type is in the Pacific Creek study site and the other in the Elk Ranch Reservoir site.

\begin{tabular}{|c|c|c|c|c|}
\hline \multicolumn{5}{|c|}{$\begin{array}{l}\text { Table 2. Regression formulas used to calculate unique animals } \\
\text { captured per number of trap-nights of effort. The formulas allow } \\
\text { comparison to other data sets calculated with varying trap-nights of } \\
\text { effort (within the range of values bracketing the regression). } \\
\text { Abbreviations for species are: P. man. (Peromyscous maniculatus); } \\
\text { C. gapp. (Clethrionomys gapperi); Tamias (Tamius amoenus and } \\
\text { minimus); Microtis (Microtis montanus and pennsylvanicus); Z. } \\
\text { prin. (Zapus princips). All p values less than } 0.01 \text {. }\end{array}$} \\
\hline \multicolumn{5}{|c|}{ Year 1999} \\
\hline Habitat & Species & Trap/ 1 & Adj. $r^{2}$ & Formula \\
\hline $1 \mathrm{M} 6$ & P. man. & 1369 & 0.85 & $Y=0.007 X+3.44$ \\
\hline 1P1 & C. gapp. & 1179 & 0.98 & $\mathrm{Y}=0.011 \mathrm{X}+1.08$ \\
\hline 1P1 & Tamias & 1179 & 0.84 & $Y=0.008 X+1.27$ \\
\hline $1 \mathrm{M} 3$ & Microtis & 2100 & 0.97 & $\mathrm{Y}=0.012 \mathrm{X}-1.99$ \\
\hline $1 \mathrm{M} 3$ & P. man. & 2100 & 0.89 & $Y=0.012 X-5.50$ \\
\hline $1 \mathrm{M} 2$ & Microtis & 1076 & 0.97 & $Y=0.065 X-9.04$ \\
\hline $1 \mathrm{M} 1$ & Microtis & 1070 & 0.99 & $Y=0.048 X-3.65$ \\
\hline \multicolumn{5}{|c|}{ Year 2000} \\
\hline $1 \mathrm{M} 6$ & P. man. & 1554 & 0.63 & $Y=0.005 X+1.60$ \\
\hline 1P1 & Tamias & 1407 & 0.87 & $\mathrm{Y}=0.005 \mathrm{X}+1.78$ \\
\hline 1P1 & C. gapp. & 1407 & 0.36 & $\mathrm{Y}=0.001 \mathrm{X}-0.63$ \\
\hline $1 \mathrm{M} 3$ & Microtis & 1511 & 0.90 & $Y=0.002 X+1.07$ \\
\hline $1 \mathrm{M} 3$ & P. man. & 1511 & 0.97 & $\mathrm{Y}=0.013 \mathrm{X}-0.57$ \\
\hline $1 \mathrm{M} 2$ & Microtis & 1190 & 0.99 & $Y=0.040 X-1.87$ \\
\hline $1 \mathrm{M} 1$ & Microtis & 836 & 0.97 & $Y=0.106 X+3.14$ \\
\hline \multicolumn{5}{|c|}{ Year 2001} \\
\hline $1 \mathrm{M} 6$ & P. man. & 706 & 0.95 & $Y=0.018 X+2.61$ \\
\hline 1P1 & Tamias & 718 & 0.83 & $\mathrm{Y}=0.014 \mathrm{X}-1.38$ \\
\hline $1 \mathrm{P} 1$ & P. man. & 718 & 0.92 & $\mathrm{Y}=0.007 \mathrm{X}-0.98$ \\
\hline $1 \mathrm{M} 3$ & Microtis & 1005 & 0.66 & $\mathrm{Y}=0.003 \mathrm{X}+1.89$ \\
\hline $1 \mathrm{M} 3$ & P. man. & 1005 & 0.88 & $\mathrm{Y}=0.005 \mathrm{X}+1.41$ \\
\hline $1 \mathrm{M} 2$ & Microtis & 1073 & 0.96 & $\mathrm{Y}=0.037 \mathrm{X}-6.71$ \\
\hline $1 \mathrm{M} 1$ & Microtis & 941 & 0.99 & $Y=0.050 X-0.61$ \\
\hline \multicolumn{5}{|c|}{ Year 2002} \\
\hline $1 \mathrm{M} 6$ & P. man. & 1063 & 0.92 & $\mathrm{Y}=0.008 \mathrm{X}+2.83$ \\
\hline 2M6 & P. man. & 959 & 0.97 & $Y=0.017 X-0.13$ \\
\hline 2M6 & Tamias & 959 & 0.92 & $Y=0.006 X-0.36$ \\
\hline 1P1 & Tamias & 961 & 0.83 & $\mathrm{Y}=0.007 \mathrm{X}+3.64$ \\
\hline 2P1 & Tamias & 963 & 0.67 & $\mathrm{Y}=0.001 \mathrm{X}+0.82$ \\
\hline $2 \mathrm{P} 1$ & C. gap. & 963 & 0.50 & $Y=0.004 X+0.32$ \\
\hline $1 \mathrm{M} 3^{1}$ & P. man. & 997 & & \\
\hline 2M3 & P. man & 959 & 0.92 & $Y=0.006 X-0.91$ \\
\hline $1 \mathrm{M} 2$ & Microtis & 1081 & 0.97 & $\mathrm{Y}=0.025 \mathrm{X}-3.95$ \\
\hline $1 \mathrm{M}^{2}{ }^{2}$ & & 968 & & \\
\hline $2 \mathrm{M} 1$ & Microtis & 904 & 0.99 & $Y=0.070 X-10.19$ \\
\hline \multicolumn{5}{|c|}{ Year 2003} \\
\hline $1 \mathrm{M} 6$ & P. man. & 938 & 0.83 & $Y=0.009 X+1.03$ \\
\hline 2M6 & P. man. & 833 & 0.99 & $Y=0.040 X-0.08$ \\
\hline $2 \mathrm{M} 6$ & Tamias & 833 & 0.91 & $Y=0.014 X-1.70$ \\
\hline 1P1 & Tamias & 952 & 0.95 & $Y=0.005 X+1.88$ \\
\hline $1 \mathrm{P} 1$ & C. gap. & 952 & 0.89 & $\mathrm{Y}=0.006 \mathrm{X}-1.41$ \\
\hline 2P1 & Tamias & 953 & 0.92 & $Y=0.004 X+0.89$ \\
\hline $2 \mathrm{P} 1$ & C. gap. & 953 & 0.93 & $\mathrm{Y}=0.006 \mathrm{X}-0.36$ \\
\hline $2 \mathrm{P} 1$ & P. man. & 953 & 0.94 & $\mathrm{Y}=0.021 \mathrm{X}-2.06$ \\
\hline $1 \mathrm{M} 3$ & P. man. & 895 & 0.99 & $Y=0.024 X-2.88$ \\
\hline $2 \mathrm{M} 3$ & P. man & 950 & 0.82 & $Y=0.005 X+2.70$ \\
\hline $2 \mathrm{M} 3$ & Tamias & 950 & 0.99 & $\mathrm{Y}=0.011 \mathrm{X}+0.25$ \\
\hline
\end{tabular}

\begin{tabular}{|c|c|c|c|c|}
\hline $1 \mathrm{M} 2$ & Microtis & 959 & 0.92 & $Y=0.010 X-2.16$ \\
\hline $1 \mathrm{M} 2$ & Sorex & 959 & 0.94 & $\mathrm{Y}=0.023 \mathrm{X}-3.79$ \\
\hline $1 \mathrm{M} 1$ & Microtis & 955 & 0.92 & $Y=0.010 X-1.57$ \\
\hline $2 \mathrm{M} 1$ & Microtis & 949 & 0.99 & $Y=0.099 X+6.58$ \\
\hline 2M1 & Sorex & 949 & 0.86 & $Y=0.016 X+0.53$ \\
\hline
\end{tabular}

Only one animal captured

${ }^{2}$ No animals captured

\begin{tabular}{|c|c|c|c|c|c|}
\hline $1 \mathrm{M} 6$ & P. man. & C. gapp. & Tamias & Microtis & Z. prin. \\
\hline 1999 & 10.8 & 0.0 & 0.0 & 0.0 & 2.0 \\
\hline 2000 & 7.0 & 0.0 & 0.0 & 0.0 & 0.0 \\
\hline 2001 & $12.6^{3}$ & 0.0 & 0.0 & 0.0 & 0.0 \\
\hline 2002 & 10.8 & 0.0 & 1.0 & 0.0 & 0.0 \\
\hline 2003 & 10.0 & 0.0 & 1.0 & 0.0 & 0.0 \\
\hline \multicolumn{6}{|l|}{ 1P1 } \\
\hline 1999 & 0.0 & 12.4 & 9.3 & 0.0 & 0.0 \\
\hline 2000 & 0.0 & 0.6 & 7.3 & 0.0 & 0.0 \\
\hline 2001 & 0.0 & 0.0 & $12.9^{4}$ & 0.0 & 0.0 \\
\hline 2002 & 0.0 & 0.0 & 10.6 & 0.0 & 0.0 \\
\hline 2003 & 0.0 & 4.6 & 6.9 & 0.0 & 0.0 \\
\hline \multicolumn{6}{|l|}{$1 \mathrm{M} 3$} \\
\hline 1999 & 6.6 & 0.0 & 0.0 & 10.0 & 0.0 \\
\hline 2000 & 12.4 & 0.0 & 0.0 & 3.1 & 0.0 \\
\hline 2001 & 6.4 & 0.0 & 0.0 & 4.5 & 0.0 \\
\hline 2002 & 1.0 & 0.0 & 0.0 & 0.0 & 0.0 \\
\hline 2003 & 21.1 & 0.0 & 0.0 & 0.0 & 0.0 \\
\hline \multicolumn{6}{|l|}{ 1M2 } \\
\hline 1999 & 0.0 & 0.0 & 0.0 & 56.1 & 0.0 \\
\hline 2000 & 0.0 & 0.0 & 0.0 & 37.7 & 0.0 \\
\hline 2001 & 0.0 & 0.0 & 0.0 & 29.8 & 0.0 \\
\hline 2002 & 0.0 & 0.0 & 0.0 & 21.1 & 0.0 \\
\hline 2003 & 0.0 & 0.0 & 0.0 & 7.9 & 0.0 \\
\hline \multicolumn{6}{|l|}{$1 \mathrm{M} 1$} \\
\hline 1999 & 0.0 & 0.0 & 0.0 & 43.9 & 0.0 \\
\hline 2000 & 0.0 & 0.0 & 0.0 & 109.0 & 0.0 \\
\hline 2001 & 0.0 & 0.0 & 0.0 & 48.6 & 0.0 \\
\hline 2002 & 0.0 & 0.0 & 0.0 & 0.0 & 0.0 \\
\hline 2003 & 0.0 & 0.0 & 0.0 & 8.4 & 0.0 \\
\hline \multicolumn{6}{|l|}{ 2M6 } \\
\hline 2002 & 16.9 & 0.0 & 5.6 & 0.0 & 0.0 \\
\hline 2003 & 39.9 & 0.0 & 12.3 & 0.0 & 0.0 \\
\hline \multicolumn{6}{|l|}{ 2P1 } \\
\hline 2002 & 0.0 & 4.3 & 1.8 & 0.0 & 0.0 \\
\hline 2003 & 18.9 & 5.6 & 4.9 & 0.0 & 0.0 \\
\hline \multicolumn{6}{|l|}{$2 \mathrm{M} 3$} \\
\hline 2002 & 5.3 & 0.0 & 0.0 & 0.0 & 0.0 \\
\hline 2003 & 7.7 & 0.0 & 11.2 & 0.0 & 0.0 \\
\hline \multicolumn{6}{|l|}{$2 \mathrm{M} 1$} \\
\hline 2002 & 0.0 & 0.0 & 0.0 & 59.8 & 0.0 \\
\hline 2003 & 0.0 & 0.0 & 0.0 & 105.6 & 0.0 \\
\hline
\end{tabular}

${ }^{3}$ This estimate is extended $39 \%$ beyond the range of the calculated regression, but the adjusted $r^{2}$ is 0.95 .

${ }^{4}$ This estimate is extended $41 \%$ beyond the range of the calculated regression, but the adjusted $r^{2}$ is 0.83 . 


\begin{tabular}{|c|c|c|c|c|c|}
\hline 2002 & P. man. & C. gapp. & Tamias & Microtis & Z. prin. \\
\hline $1 \mathrm{M} 6$ & 10.8 & 0.0 & 1.0 & 0.0 & 0.0 \\
\hline 2M6 & 16.9 & 0.0 & 5.6 & 0.0 & 0.0 \\
\hline 1P1 & 0.0 & 0.0 & 10.6 & 0.0 & 0.0 \\
\hline $2 \mathrm{P} 1$ & 0.0 & 4.3 & 1.8 & 0.0 & 0.0 \\
\hline $1 \mathrm{M} 3$ & 1.0 & 0.0 & 0.0 & 0.0 & 0.0 \\
\hline $2 \mathrm{M} 3$ & 5.3 & 0.0 & 0.0 & 0.0 & 0.0 \\
\hline $1 \mathrm{Ml}$ & 0.0 & 0.0 & 0.0 & 0.0 & 0.0 \\
\hline $2 \mathrm{M} 1$ & 0.0 & 0.0 & 0.0 & 59.8 & 0.0 \\
\hline \multicolumn{6}{|l|}{2003} \\
\hline $1 \mathrm{M} 6$ & 10.0 & 0.0 & 1.0 & 0.0 & 0.0 \\
\hline $2 \mathrm{M} 6$ & 39.9 & 0.0 & 12.3 & 0.0 & 0.0 \\
\hline 1P1 & 0.0 & 4.6 & 6.9 & 0.0 & 0.0 \\
\hline $2 \mathrm{P} 1$ & 18.9 & 5.6 & 4.9 & 0.0 & 0.0 \\
\hline $1 \mathrm{M} 3$ & 21.1 & 0.0 & 0.0 & 0.0 & 0.0 \\
\hline $2 \mathrm{M} 3$ & 7.7 & 0.0 & 11.2 & 0.0 & 0.0 \\
\hline $1 \mathrm{M} 1$ & 0.0 & 0.0 & 0.0 & 8.4 & 0.0 \\
\hline $2 \mathrm{M} 1$ & 0.0 & 0.0 & 0.0 & 105.6 & 0.0 \\
\hline
\end{tabular}

We estimated abundance for the sampled habitats using the Peterson technique with the Chapman adjustment. Estimates of abundance for species by habitat type from the Pacific Creek area are shown in Table 5. Table 6 shows data from trapping grids located in a given habitat type in the Pacific Creek area and data from the replicate of the same habitat type in the Elk Ranch Reservoir study area during 2002.

Table 5. Estimates of species abundance on the replicate \#1 habitat types during years 1999, 2000, 2001, and 2002. These estimates of abundance were calculated by the Peterson method (Peterson 1896) with the adjustment by Chapman (1951) if there is a standard deviation. In cases where there is a number without a standard deviation, it represents the raw number of individuals trapped and was too small for calculating an estimate. The table also depicts rainfall through June for each year. We then compared small mammal abundance against level of rainfall through June. We have just four years to compare, so we report any $p$ value less than $p=0.25$.

\begin{tabular}{|llrrlll|}
\hline \hline & Species & \multicolumn{5}{c|}{ Abundance + Std. Deviation } \\
& & 1999 & 2000 & 2001 & 2002 & 2003 \\
& & & & & & \\
1M6 & P. man. & $9 \pm 1.4$ & $13 \pm 2.2$ & $9 \pm 0.7$ & $7 \pm 6.4$ & $6 \pm 1.7$ \\
1P1 & C. gapp & $18 \pm 5.6$ & $4 \pm 6.0$ & 0 & 0 & 4 \\
$1 \mathrm{P} 1$ & Tamias & $5 \pm 1.5$ & $4 \pm 1.3$ & $5 \pm 0.4$ & $4 \pm 1.7$ & $4 \pm 4.3$ \\
1M3 & Microtis & $41 \pm 14.3$ & $11 \pm 1.4$ & $2 \pm 0.8$ & 0 & 0 \\
1M3 & P. man. & $19 \pm 2.7$ & $11 \pm 0.9$ & $7 \pm 2.3$ & 1 & $11 \pm 2.2$ \\
1M2 & Microtis $110 \pm 25.4$ & $49 \pm 6.3$ & $38 \pm 7.6$ & $21 \pm 25.5$ & $9 \pm 12$ \\
\hline
\end{tabular}

\begin{tabular}{|llllll|}
\hline $1 \mathrm{Ml} \quad$ Microtis & $63 \pm 12.2$ & $54 \pm 2.2$ & $31 \pm 1.6$ & 0 & $9 \pm 12$ \\
$\begin{array}{l}\text { Rainfall } \\
\text { through June }\end{array}$ & $106.7 \mathrm{~cm}$ & $82.7 \mathrm{~cm}$ & $67.5 \mathrm{~cm}$ & $87.5 \mathrm{~cm}$ & 81.3 \\
\hline
\end{tabular}

Table 6. Estimates of species abundance on the replicate \#2 habitat types during 2002. These estimates of abundance are calculated by the Peterson method (Peterson 1896) with the adjustment by Chapman (1951).

\begin{tabular}{|llcc|}
\hline \hline Habitat & Species & $\begin{array}{c}\text { Abundance + Std. Deviation } \\
\end{array}$ & \\
& & & 2002 \\
2M6 & P. man. & $10 \pm 2.5$ & $26 \pm 44.3$ \\
2P1 & C. gapp. & 2 & 4 \\
2P1 & P. man. & 0 & $15 \pm 8.8$ \\
2P1 & Tamias & 1 & 4 \\
2M3 & P. man. & 5 & 7 \\
2M3 & Tamias & 0 & $6 \pm 7$ \\
2M1 & Microtis & $38 \pm 230$ & $136 \pm 73$ \\
\hline
\end{tabular}

Total unique captures per 1,000 trap nights for all species were correlated to estimates of abundance for all species $(p=0.01)$. We compared number of individuals per 1,000 trap-nights for each one-hectare plot of $1 \mathrm{P} 1,1 \mathrm{M} 6,1 \mathrm{M} 3,1 \mathrm{M} 2$, and $1 \mathrm{M} 1$ across years using a $G$ test. There was no significant difference across years for deer mice on 1M6 or for Tamias on the 1P1. There was a significant difference across years for red-backed voles on the 1P1 plot $(G=16.4$, d.f. $=4, p<0.001)$, for deer mice on the 1M3 plot $(G=25.9$, d.f. $=4, p<0.001)$, for Microtis on the $1 \mathrm{M} 3$ plot $(G=14.8$, d.f. $=4, p<$ $0.005)$, for Microtis on the $1 \mathrm{M} 2 \operatorname{plot}(G=45.8, d . f .=$ $4, p<0.001)$, and for Microtis on the $1 \mathrm{M} 1 \operatorname{plot}(G=$ 188.7, d.f. $=4, p<0.001$ ). Comparing the two years of data on the Uhl hill area by $G$ test, there were significant differences for deer mice on the 2M6 $(G=$ 9.7, d.f. $=1, p<0.005)$ and deer mice in the 2P1 $(G=$ 20.96, d.f. $=1, p<0.001$ ), and Microtis in the 2M1 $(G=12.7, d . f .=1, p<0.001)$.

Level of precipitation at nearest weather station to our study area through June of each year in our study area was $106.7 \mathrm{~cm}$ (1999), $82.7 \mathrm{~cm}$ (2000), $67.5 \mathrm{~cm} \mathrm{(2001),} 87.5 \mathrm{~cm}$ (2002), and 81.3 (2003). There were no significant differences when we compared number trapped per 1,000 trap-nights to rainfall. When we compared the estimates of abundance across a given habitat type over the five years to level of precipitation, we found that abundance of Microtis in $1 \mathrm{M} 3\left(r^{2}=0.69, p=0.08\right)$ and red-backed voles in $1 \mathrm{P} 1\left(r^{2}=0.74, p=0.06\right)$ w ere somewhat related to level of precipitation (Table 5). P recipitation data came from the U.S. D epartment of A griculture precipitation station located Two Ocean Plateau from 1999 to 2002. In 2003, there were no data from Two Ocean Plateau, so we used data from Cottonwood Creek. Interestingly, in the wettest habitat (1M1) we 
between number of individual Microtis trapped in one year compared to the rainfall of the previous year and the estimate of abundance in one year compared to the rainfall in the previous year $\left(r^{2}=0.75, p=\right.$ 0.13). The 2M1 plot, located near Elk Ranch Reservoir, maintained its swampy condition because it is fed by irrigation, and thus maintained a high number of Microtis.

At this point genetic analyses of carnivore scat are still in progress. During 2001 - 2003, we walked $95.5 \mathrm{~km}$ of trails (twice) in the Pacific Creek area to collect scat; $23.5 \mathrm{~km}$ were in M6, $18.9 \mathrm{~km}$ were in $\mathrm{M} 3,7.7 \mathrm{~km}$ in $\mathrm{M} 2$, and $45.5 \mathrm{~km}$ were in P1 habitats. In 2001, we found 17 fresh coyote scats in M6 habitat, 18 in M3, 12 in M2, and 21 in P1. In 2002, we found 5 fresh coyote scats in M6, 4 in M3, 1 in M2, and 12 in P1. In 2003, there were 6 scats in M6, 15 in M3, 2 in M2, and 11 in P1. In total for Pacific Creek over all the years, there were 28 scats in M6, 37 in M3, 15 in M2, and 44 in P1. We would have expected 30.5 scats in M6, 24.6 scats in M3, 10 scats in M2, and 58.9 scats in P1. That represents a significant difference from numbers of scats expected per habitat type of the Pacific Creek area $\left(X^{2}=12.7\right.$, d.f. $=3, p=.005)$. So, there were more than expected in M3 and M2 meadows, but fewer than expected in the forests.

In 2002 and 2003, we also sampled $47.5 \mathrm{~km}$ of trails (twice) in the Elk Ranch Reservoir area. In this area, $31.7 \mathrm{~km}$ were in M6, $8.7 \mathrm{~km}$ were in M3, $3.3 \mathrm{~km}$ were in $\mathrm{M} 2$, and $3.7 \mathrm{~km}$ were in P1. During 2002, there were 5 in M6, 7 in M3, 1 in M2, and 1 in P1. During 2003, there were 11 in M6, 3 in M3, 1 in $\mathrm{M} 2$, and 3 in P1. In total, there were 16 in M6, 10 in M3, 2 in M2, and 4 in P1. There was no significant difference in location of scats by habitat type across both years in the Elk Ranch Reservoir area.

When combining the data from the Pacific Creek area and the Elk Ranch Reservoir area (by habitat type), we found no significant difference in location of coyote scats during the 2002 field season, but there was a significant difference during $2003\left(X^{2}\right.$ $=7.99, d . f$. $=3, p<0.05)$. The habitat type contributing most to that difference was M3, with more observed than expected.

We walked the same trails in the Pacific Creek area during 2001 - 2003, but we collected 68 fresh coyote scats in 2001, 22 in 2002, and 34 in $2003\left(X^{2}=27.5\right.$, d.f. $\left.=2, p<0.001\right)$. Number of scats has declined significantly in 2002 and 2003. Those two years saw a fast expansion of wolves in the Teton Pack. There was no significant difference in the number of scat collected around the Elk Ranch when we compared 2002 and 2003.

During 2002 and 2003, there were no significant differences in the number of scats located in the Pacific Creek area as opposed to the Elk Ranch Reservoir area (adjusted for differences in total transect length at each site). That could indicate that wolves are affecting coyotes evenly over both areas. Both areas are also subject to the same weather changes, but the 2M1 plot near Elk Ranch Reservoir maintained its swampy characteristics, probably because it is fed by irrigation run-off.

At this point, we lack sample size in the $X^{2}$ matrix to analyze bear and pine martin scat by habitat type, but pine martin scat is heavily weighted toward the P1 habitat and bear scat is more common in the P1 and M3 habitats.

\section{$\downarrow \quad$ IMPACTS OF CARNIVORES ON PREY AND Plants}

It is difficult to predict how the presence of wolves will affect the members of the mammal community we are sampling, and the farther the indirect effects trickle through the food web, the more difficult the predictions become. Long-term monitoring data from the boreal forest of Isle Royale indicated that predation by wolves affects the number and behavior of moose (Alces alces) (McLaren and Peterson 1994). This, in turn, affected the balsam fir forest (and other woody plants) by regulating seedling establishment, sapling recruitment, sapling growth rates, litter production in the forest, and soil nutrient dynamics (Pastor et al. 1988; Post et al. 1999 and references within).

Crête and Manseau (1996) and Crête (1999) compared the biomass of ungulates to primary productivity along latitudinal gradients. For the same latitude, ungulate biomass was five to seven times higher in areas where wolves were absent compared to where wolves were present (Crête 1999). Overabundance of ungulates has been shown to reduce numbers of native rodent species, cause declines in understory nesting birds, obliterate understory vegetation in some forests, and even eliminate regeneration of the forest canopy (Alverson 1988, 1994; McShea \& Rappole 1992; McShea et al. 1997; and Berger et al. 2001). Ripple and Larson (2000) reported that aspen (Populus tremuloides) overstory recruitment ceased when wolves disappeared from Yellowstone National Park. 
We stress that the subtleties of interactions can vary significantly under different environmental conditions. Abiotic factors (Connell 1978), climatic patterns (Ballard and Van Ballenberghe 1997; Post et al. 1999), and seasonality (Boyce et al. 1999) can change the relative strength of ecological interactions. Furthermore, the number of interactive links in a food web can influence how a community behaves with or without predators (for a recent review, see Miller et al. 2001).

Thus, we expect that data from areas with wolves would show a lower abundance of coyotes (Crabtree and Sheldon 1999), and the 2002 and 2003 scat data on coyotes from the Grand Tetons preliminarily support that idea. As one looks farther across the trophic levels, however, the impact becomes harder to predict. We speculate that lower numbers of coyotes should reduce predation pressure on some voles and mice, thus allowing their numbers to increase. Fewer coyotes, however, may also reduce predation pressure on smaller predators like foxes (Vulpes vulpes), badgers, and weasels (Mustela frenata) (sensu Henke and Bryant 1999), and higher mesopredator numbers may decrease numbers of other rodent species. Weasels alone can drive vole cycles.

Wolves could also decrease the number of ungulates in the area (Crête and Manseau 1996; Boyce and Anderson 1999; Crête 1999), and ungulates compete with some rodents for forage (Keesing 2000). Fewer ungulates should allow those rodents access to more forage and thus promote growth of their numbers.

With wolves present, rodent species strongly affected by coyote predation may be released (ecologically) when coyotes decline. With less topdown pressure from coyotes, and before smaller carnivore numbers begin to rise, these rodents may be strongly regulated by resource levels, showing a tighter relationship to rainfall than rodents regulated by predation. After a lag, fewer coyotes may increase numbers of badgers, weasels, and foxes. If those smaller predators choose different rodent prey than coyotes, those rodent species may show less of a relationship to rainfall and more of a relationship to mesopredator abundance. These rodents may show higher levels of reproduction as they would exist under heavy predation pressure. If predation by coyotes and mesopredators is redundant for some species of rodent, there may be little change in the numbers of those rodents (and in their reproductive rates) when wolves arrive. Rodent species strongly regulated by competition with elk may increase in number with wolves (if wolves can reduce the high numbers of elk significantly).

We hope to test these ideas over time. Our work will be conducted on the small and mediumsized mammal community, in collaboration with Debinski et al. analyzing the avian and plant communities at the same sites. Understanding how communities respond in the presence and absence of carnivores will be important to management decisions in areas that evolved with predation as a strong evolutionary factor. Such knowledge will also allow the creation of predictive models that show the potential for restoring a natural state to the Greater Yellowstone Ecosystem area.

\section{Literature Cited}

Alverson, W. S., W. Kuhlmann y D. M. Waller. 1994. Wild forests: conservation biology and public policy. Island Press, Washington, D. C.

Alverson, W. S., D. M. Waller y S. L. Solheim. 1988. Forests too deer: edge effects in northern $\mathrm{W}$ isconsin. Conservation $\mathrm{B}$ iology 2:348-358.

Ballard, W.B. and V. Van Ballenberghe, 1997. Predator/prey relationships. Pp. 247-273 In Ecology and management of the North American moose. A.W. Franzman and C.C. Schwartz, (Eds.). Smithsonian Institution Press, Washington DC.

Beauvais, G.P. and S.W. Buskirk. 1999. Modifying estimates of sampling effort to account for sprung traps. Wildlife Society Bulletin 27: 39-43.

Berger, J., P.B. Stacey, L. Bellis, and M.P. Johnson. 2001. A mammalian predator-prey imbalance: Grizzly bear and wolf extinction affect avian neotropical migrants. Ecological Applications 11: 947-960.

Boyce, M.S. and E.M. Anderson. 1999. Evaluating the role of carnivores in the Greater Yellowstone Ecosystem. Pp. 265-283 in Carnivores in Ecosystems: The Yellowstone experience. (Eds.) T.W. Clark, A.P. Curlee, S.C. Minta, and P.M. Kareiva. Yale University Press, New Haven Connecticut. 
Boyce, M.S., A.R.E. Sinclair, and G.C. White. 1999. Seasonal compensation of predation and harvesting. Oikos 87: 419-426.

Caughley, G. 1977. Analysis of vertebrate populations. John Wiley and Sons, New York, New York.

Chapman, D.G. 1951. Some properties of the hypergeometric distribution with applications to zoological censuses. University of California Publications on Statistics 1: 131-160.

Clark, T.W. and M.R. Stromberg. 1987. Mammals in Wyoming. University of Kansas Museum of Natural History, Lawrence, Kansas, USA.

Connell, J.H. 1978. Diversity in tropical rain forests and coral reefs. Science 199: 1302-1310.

Crabtree, R.L. and J.W. Shelton. 1999. Coyotes and canid coexistence in Yellowstone. Pp. 127163 in Carnivores in Ecosystems: The Yellowstone experience. (Eds.) T.W. Clark, A.P. Curlee, S.C. Minta, and P.M. Kareiva. Yale University Press, New Haven Connecticut.

Crête, M. 1999. The distribution of deer biomass supports the hypothesis of exploitation ecosystems. Ecological Letters 2: 223-227.

Crête, M. and M. Manseau. 1996. Natural regulation of cervidae along a $1000 \mathrm{~km}$ latitudinal gradient: change in trophic dominance. Evolutionary Ecology 10: 51-62.

Crooks, K. and M. Soulé. 1999. In a fragmented system. Nature 400: 563-566.

Debinski, D.M., K. Kindscher, M.E. Jakubauskus. 1996. Biodiversity and Remotely Sensed Habitat Types: A Comparison of Montane Meadows in the Gallatin Range, MT and in Grand Teton National Park, WY. University of Wyoming, National Park Service Research Center $20^{\text {th }}$ Annual Report, pp. 4549.

Dobson, A.P. and R.M. May. 1986. Disease and Conservation pp. 345-365 in Conservation Biology: The Science of Scarcity and Diversity. Sinauer Associates, Sunderland, Massachusetts, USA.
Henke, S.E. and F.C. Bryant. 1999. Effects of coyote removal on the faunal community in western Texas. Journal of Wildlife Management 63: 1066-1081

Hoogland, J.L. 1995. The black-tailed prairie dog: Social life of a burrowing mammal. University of Chicago Press, Chicago, Illinois.

Hunter M.D. and P.W. Price. 1992. Playing chutes and ladders: Heterogeneity and the relative roles of bottom-up and top-down forces innatural communities. Ecology 73: 724732.

Karanth K. U. and Nichols J. D. 2000. Ecological Status and Conservation of Tigers in India. Final Technical Report to the US Fish and Wildlife Service (Office of International Affairs).

Keesing, F. 2000. Crytic consumers and the ecology of an African Savanna. BioScience 50: 205215.

Kendall, M.G. and J.D. Gibbons. 1990. Rank correlation methods. Edward Arnold, London, U.K.

Kohn, M.H., E.C. York, D.A. Kamradt, G. Haught, R.M. Sauvajot, and R.K. Wayne. 1999. Estimating population size by genotyping faeces. Proceedings of the Royal Society of London 266: 657-663.

Krebs, C.J., S. Boutin, R. Boonstra, A.R.E. Sinclair, J.N.M. Smith, M.R.T. Dale, and R. Turkington. 1995. Impact of food and predation on the snowshoe hare cycle. Science 269: 1112-1114.

Lancia, R.A., J.D. Nichols, and K.H. Pollock. 1994. Estimating the number of animals in wildlife populations. Pp. 215-253 in Research and Management Techniques for Wildlife and Habitats. Ed. T.A. Bookhout, The Wildlife Society, Bethesda, Maryland.

Mann, H.B. 1945. Non-parametric tests against trend. Econometrica 13: 245-259.

McLaren, B. E. and R. O. Peterson. 1994. Wolves, moose and tree rings on Isle Royale. Science 266: 1555-1558. 
McShea, W. and J. Rappole. 1992. White-tailed deer as a keystone species within forested habitats of Virginia. Virginia Journal of Science 43: 177-186.

McShea, W.J., H.B. Underwood, and J.H. Rappole (Eds.). 1997. The science of overabundance: Deer ecology and management. Smithsonian Institution Press, Washington D.C.

Miller, B., B. Dugelby, D. Foreman, C. Martinez del Río, R. Noss, M. Phillips, R. Reading, M.E. Soulé, J. Terborgh, L. Willcox. 2001. The importance of large carnivores to healthy ecosystems. Endangered Species UPDATE 18: 202-209.

Noss, R.F. and A. Copperrider. 1994. Saving Nature's Legacy: Protecting and Restoring Biodiversity. Island Press, Covelo, California, USA.

Noss, R.F., M.A. O'Connell, and D.D. Murphy. 1996. The Science of Conservation Planning: Habitat Conservation under the Endangered Species Act. Island Press, Covelo, California, USA.

Oksanen, L. and T. Oksanen. 2000. The logic and realism of the hypothesis of exploitation ecosystems. American Naturalist 155: 703723.

Otis, D.L., K.P. Burnham, G.C. white, and D.R. Anderson. 1978. Statistical inference from capture data on closed animal populations. Wildlife Monograph 62.

Pastor, J., R.J. Naiman, and B. Dewey. 1988. Moose, microbes and boreal forests. BioScience 38: 770-777.

Peterson, C.G.J. 1896. The yearly immigration of young plaice into the Limfjord from the German Sea. Reproductions of the Danish Biological Station 6: 1-48.

Pickett, S.T.A. and P.S. White. 1985. The Ecology of Natural Disturbance and Patch Dynamics. Academic Press, Orlando, Florida, USA.
Pinter, A.J. 1996. Climatic Factors, Reproductive Success and Population Dynamics in the Montane Vole, Microtus montanus. University of Wyoming and the National Park Service Research Center Annual Report, pp. 88-90.

Polis G.A. and D.R. Strong. 1996. Food web complexity and community dynamics. American Naturalist 147: 813-846.

Post, E., R.O. Peterson, N.C. Stenseth, and B.E. McClaren. 1999. Ecosystem consequences of wolf behavioural response to climate. Nature 401: 905-907.

Ripple, W.J. and E.J. Larsen. 2000. Historic aspen recruitment, elk, and wolves in northern Yellowstone National Park, USA. Biological Conservation 95: 361-370.

Sinclair, A.R.E. 1991. Science and the practice of wildlife management. Journal of Wildlife Management 55: 767-773.

Terborgh, J., J. Estes, P. Paquet, K. Ralls, D. Boyd, B. Miller, and R. Noss. 1999. Role of top carnivores in regulating terrestrial ecosystems. In press in The Science of Continental Scale Reserve Design. M. Soulé, and J. Terborgh (eds.). Island Press, Covelo, California, USA.

Terborgh, J., L. Lopez, P. Nuñez V., M. Rao, G. Shahabuddin, G. Orihuela, M. Riveros, R. Ascencio, G.H. Adler, T.D. Lambert, and L. Balbas. 2001. Ecological meltdown in predator-free forest fragments. Science 294: 1923-1926.

Thompson, W.L., G.C. White, and C. Gowan. 1998. Monitoring Vertebrate Populations. Academic Press, New York, New York, USA.

White, G.C., D.R. Anderson, K.P. Burnham, D.L. Otis. 1982. Capture-recapture and removal methods for sampling closed populations. Los Alamos National Laboratory, LA-8787NERP, Los Alamos, New Mexico.

Zar, J.H. 1984. Biostatistical analysis ( $2^{\text {nd }}$ Edition). Prentice-Hall, Inc. Englewood Cliffs, New Jersey, USA. 